\title{
VIJA STIKĀNE
}

Īpaši aizsargājamais kultūras piemineklis Turaidas muzejrezervāts, Latvija

\section{VIDUSLAIKU PERGAMENTA DOKUMENTI UN LİBIEŠU VIETVĀRDI}

\section{İss kopsavilkums}

Rakstā analizēti Turaidas pilī tapuši dokumenti latīṇu valodā, kas publicēti grāmatā Turaida 13.-16. gadsimta dokumentos (2014). Senākie Turaidā 1239.1252. gadā izdotie dokumenti sniedz ziṇas par zemju valdījumu noformēšanu, un vairāki attiecas uz Rīgas domkapitula nodrošinājumu, un tajos atrodami arī viduslaiku Turaidas un Krimuldas pilsnovada vietvārdi. Apvienojumā ar 16. gs. vidus avotiem, kā arī 17. gs. zemju revīzijām šñ informācija l,auj lokalizēt 13. gs. dokumentos minētās vietas un izsekot latīṇu tekstos ietverto vietvārdu attīstībai.

Atstlēgvārdi: Turaidas mūra pils, Krimuldas pilsnovads, pergamenta dokumenti, vietvārdi, Gaujas lībieši.

Senākie Turaidā izdotie pergamenta dokumenti latīṇu valodā par zemju valdījumu noformēšanu Livonijā un Rīgas domkapitula nodrošinājumu tapuši Rīgas bīskapa Nikolaja (Nicolaus, amatā 1230-1253) laikā (Stikāne 2014, 28-36, Nr. 8-11). Rīgas domkapituls bija bīskapa (no 1255. gada - Rīgas arhibīskapa) padome laicīgajās un garīgajās lietās, un tā vadīja bīskapijas pārvaldi. To veidoja 12 vai 13 kanoniķu jeb domkungu kolēgija. Domkapituls pārraudzīja baznīcas finanses un nodrošināja bīskapa/arhibīskapa amata pēctecību (Levāns 2013, 66). Domkapitulam piederēja vairāki novadi un pilis: 13.-14. gs. Dole, Krimulda un Dundaga, bet 15.-16. gs. Dole, Krimulda un Suntaži (Šterns 2002, 206, 402).

Rakstā aplūkotie dokumenti latīnu valodā rakstīti uz pergamenta un sākotnēji tikuši uzglabāti Rīgas bīskapa/arhibīskapa un Rīgas domkapitula arhīvā, bet mūsdienās ir atrodami dažādu valstu dokumentu krātuvēs, kur nonākuši sarežğìtu vēstures notikumu rezultātā. Kā norādījis vēsturnieks Teodors Zeids (1912-1994), līdz mūsdienām no Rīgas bīskapa/arhibīskapa un Rīgas domkapitula arhīva nonākuši 233 pergamenta 
oriǵināldokumenti vai to transsumti jeb apliecināti noraksti, kas attiecas uz laiku no 1209. līdz 1438. gadam. Laikā, kad notika Rīgas arhibīskapa cīṇa ar Vācu ordeni Livonijā, Rīgas domkapitula pārstāvji šos dokumentus aizveda uz Lībeku un deponēja Lībekas domkapitula arhīvā. Livonijā palikušie arhīvi gāja bojā 16. gadsimtā. Rīgas arhibīskapa koadjutors Mēklenburgas Kristofs uz Lībeku aizvestos dokumentus ieguva 1563. gadā, bet vēlāk bija spiests tos atdot Polijas-Lietuvas karalim. Tādējādi šì vēl saglabājusies arhīva daḷa nonāca Polijas karaḷu arhīvā Krakovā. Kad 1765. gadā Krakovas arhīvs tika pārvests uz Varšavu, 31 no Rīgas bīskapa/arhibīskapa un Rīgas domkapitula arhīva dokumentiem palika Krakovā, kur saglabājās lielās Polijas magnātu dzimtas Čartorisku - bibliotēkā. 1794. gadā Rīgas bīskapa/arhibīskapa un Rīgas domkapitula arhīvs tika pārvests no Varšavas uz Krieviju un sadalīts starp Pēterburgas publisko bibliotēku un Maskavas Seno aktu arhīvu. 1925. gadā 123 Rīgas bīskapa, arhibīskapa un domkapitula arhīva dokumenti tika atdoti Polijai, kur tie uzglabāti Galvenajā seno aktu arhīvā Varšavā. Pārējie palika Maskavas Seno aktu arhīvā. Līdzīgs liktenis tikt pārvietotam piemeklēja arī Vācu ordeṇa Livonijas atzara arhīvu, kura daḷa pašlaik ir Stokholmā, bet dạ̣a gājusi bojā. Vācu ordeṇa arhīvs no Kaḷiņingradas (vācu - Königsberg, lietuviešu - Karaliaučius) Valsts arhīva pēc Otrā pasaules kara nonāca Berlīnē (Geheimes Staatsarchiv Preußischer Kulturbesitz) (Zeids 1992, 45-46, 62).

Senākais Turaidas mūra pilī tapušais dokuments ir 1239. gada 19. aprīlīi izdotais apliecinājums par Jersikas pils daḷas dāvināšanu Vācu ordenim Livonijā un iespējamo Jersikas lēṇa mantinieku nodrošinājumu. No šī dokumenta Vācu ordeṇa arhīvā Prūsijā bija saglabājies oriǵināltranssumts, kas 1415. gada 14. decembrī izgatavots uz pergamenta un 1940. gadā atradies Kēnigsbergas Valsts arhīvā. Dokumenta teksts ir bijis publicēts vairākkārt (LUB I, Nr. 163; SLVA, 222-2240), taču 2014. gadā pirmoreiz pilnībā tulkots latviešu valodā. Tāpat kā citus latīṇu dokumentus Turaidas izdevumā, arī šo tulkojusi Brigita Cīrule. Dokumentā minēti vairāki vietvārdi - lībiešu, latgaḷu izcelsmes vai t. s. hibrīdi (nosaukumi ar dažādu maztautu ietekmi, skat. Bušs 2007, 41-42; Bušs 2003, 69-70): Gerceke, Duna, Livonia, Zegewalt, Lenewarde, Ykescole, Kokenes, Thoreidhia (Jersika, Daugava, Livonija, Sigulda, Lielvārde, Ikšķile, Koknese, Turaida).

Nozīmīgs Turaidas un Krimuldas pilsnovada vēsturei ir Rīgas bīskapa Nikolaja izdotais apstiprinājums Rīgas domkapitulam. Ar šo 
dokumentu, kas izdots Turaidā (Toreidia) 1248. gada 16. augustā, viṇš nostiprināja valdījumus agrāk dāvinātajos īpašumos, kā arī kundzību Turaidā, Lielvārdē un Remīnes pilsnovadā. Tas uzskatīts arī par viltojumu, taču vairāki iepriekš minēto vietu nosaukumi sastopami jau pāvesta Gregorija IX (Gregorius IX, 1145-1241) dokumentā, kas apstiprināts 1231. gadā (LGU I, 15). Dokuments bijis nozīmīgs Rīgas domkapitulam kā īpašumtiesību apliecinājums, tāpēc ir tapuši vairāki tā eksemplāri un noraksti. Viens no oriǵināliem glabājas Varšavā, Galvenajā seno aktu arhīvā (Archiwum Główne Akt Dawnych w Warszawie; fotokopija Latvijas Nacionālajā arhīvā (LVVA-4060-2-30)), cits 19. gs. atradās Pēterburgas Ķeizariskajā bibliotēkā (tag. Государственная публичая библиотека) (Brieflade IV, 97, Taf. 22, Nr. 2). 19. gs. beigās Lietuvas metrikā, kas glabājās Maskavā, Ārlietu ministrijas arhīvā, atradās Lībekā tapis 1424. gada 19. maija transsumts.

Ar 1248. gada dokumentu tika izveidots Krimuldas pilsnovads un draudze. Šis ir viens no pirmajiem draudžu robežu aprakstiem Livonijā, kur par robežām kalpoja dabas orientieri - upes, jūras krasts (Simiński 2007, 93, 106). Dokumentā norādīts, ka Kubeseles draudzes robežas stiepjas garumā no Vikmestes (Vitkemiske) upes līdz jūrai, platumā - no Tarupes vai Ķī̌supes (Tarvisjuge) līdz Gaujai (Coiva). Krimuldas draudzes novads nemainīgi saglabājās daudzus gadsimtus. Šis dokuments nosauc šādus ciemus (villae) Krimuldas (Cubesile) draudzē: Cubesille, Olikencule, Kivemale, Cursicule, Asigalle, Moisecule, Ennisile, Viltesile, Mundrisile, Totisile, Pabasile, Gervicule, kā arī Ieikisile, Coltemale un Laugule (Kubesele, Alciems jeb Olikenkule, Kivemale, Kuršu ciems, Aizgale, Muižciems, Sēja, Vidriži, Mundrisile, Totisile, Pabaži, Jērkule, kā arī Eikaži, Bīriṇi, Laugas).

Rīgas domkungu tiesības tika regulētas arī dokumentos, kurus 1251. gada 27. jūlijā un 1252. gada 31. augustā Turaidā (Thoreidia, Toreida) izdevis Rīgas bīskaps Nikolajs. Vienā no tiem bīskaps nodeva arhidiakona tiesības visā Zemgalē sava domkapitula prāvestam, jo viņš nespēja ik gadu vizitēt visās savas bīskapijas provincēs. Dokumenta oriǵināls atrodas Krakovā, Čartorisku bibliotēkā, bet fotokopija arī Latvijas Nacionālajā arhīvā (LVVA-4060-2-7). Otrajā Rīgas bīskaps piešķir domkapitulam laicīgo tiesu varu trīs ciemos - Lovgena, Koltemala, Jeckeseile (Laugas, Bīriņi, Eikaži). Tāpat kā daudziem citiem dokumentiem, kas saistīti ar īpašuma lietām, tam bijuši vairāki oriǵināli un transsumti, kas mūdienās glabājas Galvenajā seno aktu arhīvā Varšavā (Archiwum 
Główne Akt Dawnych w Warszawie; Collectio autograophorum) un Maskavā, Seno aktu galvenajā arhīvā (Российский государственный архив древних актов, Livl. Akten nr. 2.), savukārt dokumenta transsumts, kas izdots Villa Nova 1360. gada 17. augustā, glabājas Vatikāna arhīvā Romā (Vatican archive in Rom, Regestum Innocentii papae VI).

\section{Vietvārds Turaida}

Turaidas vārda lietojums 1239.-1252. gada dokumentos cieši sasaucas ar agrākiem un vēlākiem latīṇu tekstiem. Mūsdienās Turaidas mūra pils ir daḷa no Siguldas pilsētas, kamēr Turaidas ciems (blīvi apdzīvota vieta) pieder Krimuldas novadam. Vācu valodā Turaida līdz mūsdienām saukta Treiden, Treyden, bet latviešu valodā nosaukums saistìts ar latinizēto lībiešu vārdu, kas latīṇu tekstos lietots no 13. gs. Latviešu valodā pirmais zināmais dokuments Turraidas pilī tapis 1810. gadā (LNB RXA32, 17), bet 18. gadsimtā vietējie zemnieki saukuši pili Turreda (Gadebusch 1780, 85). Uzskata, ka Turaidas nosaukums cēlies no lībiešu valodas, kas pieder pie somugru valodu saimes. Par Latvijas vietvārdiem, kam ir somugriska izcelsme, daudz rakstīts jau no 19. gs. beigām līdz mūsdienām (skat. Balode 2009, 37 u. c.), bet Turaidas apkārtnes vietvārdu analīzei savu artavu devuši valodnieki Valentīns Jūliuss Kiparskis, Tenu Karma, Laimute Balode, vēsturnieki Jānis Graudonis, Ēvalds Mugurēvičs, Ēvalds Tenisons u. c. (Bušs 1999, 28). Populārākais Turaidas vārda skaidrojums saista nosaukumu ar lokalizētu seno skandināvu pērkona dieva Tora (Tor jeb Thor) apzīmējumu, kas minēts Indriķa hronikā, runājot par sāmsaliešiem, kā Taara. Lībiešiem radniecīgajā igauṇu valodā aed nozīmē 'dārzs', līdz ar to Turaidas nosaukums tulkojams 'Tora dārzs' jeb 'Pērkona dieva dārzs' (Mägiste 1967, 155), tomēr vārda autentiskās formas noteikšanu valodnieki uzskatījuši par diskutablu (Bušs 1999, 28). Vārds 13.-16. gadsimtā rakstīts dažādi, latīṇu valodā mēǵinot atdarināt lībiešu valodas fonētisko skanējumu - Toreda, Thoreyda, Toreyde, Thoreda, Thoreida, Toreida, Toreidhia, Torreyde. Tas, pirmkārt, sastopams Indriķa hronikā, kur minēts 47 reizes kā koka pils, novada un tā iedzīvotāju turaidiešu - apzīmējums. Vēlākos gadsimtos atsevišḳos 13.-15. gs. dokumentos nosaukumi Thoreida, Thoreidera, Toreidera, Treider Aa lietoti arī kā upes Gaujas apzīmējums. Šo dokumentu un norakstu izgatavošanā iesaistīti Daugavgrīvas klostera abati $(1263,1305)$, Rīgas arhibīskaps (1350) un Rīgas domkungi (1463). No 14. gs. vārdi Treiden, Treyden sastopami viduslejasvācu tekstos un plaši lietoti kā Rīgas arhibīskapa Turaidas pils, 
novada, fogtejas centra un fogta amata apzīmējums, bet dažos gadījumos apzīmē ceḷu gar Gauju (Treidnischer, Treydensis, Via Treydense) Rīgas domkungu pārvaldītajā Krimuldas pilsnovadā.

\section{Krimuldas ciemi}

Atšķirībā no Turaidas, kas saglabāja centra statusu ilgstoši (un lokalizācijas jautājums nerada šaubas), Krimuldas pilsnovada/draudzes vietvārdi rakstītajos vēstures avotos minēti retāk. Lielākā daḷa vietvārdu 13. gs. latīnu tekstā, kurā aprakstīta Krimuldas draudzes teritorija, ir lībiešu izcelsmes, taču daḷai etimoloǵija neskaidra vai diskutabla. Tie apzīmē apdzīvotas vietas - ciemus, par ko liecina gan dokumentu saturs (1248. gadā saukti latīṇu vārdā villa), gan vairāku vārdu izskaṇas -ele, -sile, -sele, kas lībiešu valodā nozīmē apdzīvotu vietu, ciemu, novada centru, pilsapgabalu; kā arī vārda daḷas -kula, -küla, kas lībiešu un igauṇu valodās ir ciema apzīmējums (Bielenštein 1892; Westrén-Doll 1926, 10, 18; Hermann 897, 8, 12; Hirša 1994, 211). 13. gs. lībiešu ciemu iespējamās vietas 20. gs. beigās dabā identificējusi Turaidas muzejrezervāta vēsturniece Ligita Beitiņa kontekstā ar 13. gs. satiksmes ceḷu virzieniem un kopējo Gaujas lībiešu apdzīvotību (Beitiņa 1999, 22-27; skat. arī Auns 2019).

Dokumentos 13. gs. minētie vietvārdi pēc vairākiem gadsimtiem tiek nosaukti Rīgas arhibīskapijas Turaidas gala vaku grāmatā (Wackenbuch auf der Treidichen Seiten 1550) un Rīgas arhibīskapijas inventārā (Inventarium zur Erstift Riga 1564), ko vēstures literatūrā sauc arī par Piebalgas vaku grāmatu (Dunsdors, Spekke 1964, 127). Šie dokumenti tapuši vācu valodā un glabājas Šverīnes Zemes arhīvā, bet kopijas Latvijas Nacionālajā arhīvā (LVVA-4060-2-483) un Turaidas muzejrezervāta zinātniskajā arhīvā. Šajā laikā vietvārdi, kas līdzīgi 1248. gadā un 1252. gadā minētajiem, apzīmēja administratīvas vienības - vakas jeb pagastus. Krimuldas pilsnovadā, kas sakrita arī ar draudzes robežām, 16. gadsimtā bija 13 vakas jeb pagasti, kas aptvēra 322 zemnieku saimniecības. 16. gs. vidus vaku grāmatas un zemnieku sarakstus analizējuši vēsturnieki, akcentējot sociālās un ekonomiskās vēstures aspektus un vēsturisko ġeogrāfiju (Dunsdorfs, Spekke 1964, 252 ff; Vegesack 1932; Švābe 1939, 59; Auns 2009, 53-58; Vunk 2014, 40-45), bet vakas un zemnieku sētas lokalizējis Dr. hist. Muntis Auns, kurš sadarbībā ar Turaidas muzejrezervātu 2009. gadā izveidojis ekspozīcijas vajadzībām vēsturisku karti (pieejama: http://www.turaida-muzejs.lv/about/fogti/vakas/). Izstrādājot šo digitālo karti, izmantots plašs viduslaiku dokumentu klāsts latīṇu 
un viduslejas vācu valodā, kā arī 16. gs. beigu inventāri, 17.-18. gs. arklu revīzijas, zviedru mērnieku sastādītas kartes, 19.-20. gs. avoti, kas atspoguḷo apdzīvotību un tās izmaiņas. Vēsturiskās ǵeogrāfijas pētījums ḷauj izsekot arī etniskajiem procesiem Turaidas apkārtnē vairāku gadsimtu garumā (Auns 2019, 174-179).

Laika gaitā Vidzemes rietumdaḷā ir izzudusi gan senā apdzīvotības forma - ciemi (Liepiṇa 1963, 138-159; Vegesack 1932, 21-24), gan arī Vidzemes lībiešu valoda. Spriežot pēc dažādiem vēstures avotiem, t. sk. zemnieku sarakstiem un dokumentiem, jau 16. gs. vidū Krimuldas pilsnovadu pārsvarā apdzīvoja latviešu zemnieki, tikai pie jūras, mūsdienu Saulkrastu teritorijā, vēl bija sastopami lībiešu ciemi (Auns 2009, 53-58). Visilgāk lībiešu valoda bija dzirdama Vidzemes ziemeḷdaḷā, kur Salacas lìbiešu izloksne pierakstīta vēl 19. gs. (Pajusalu 2009, 42-48, 77; Ariste 1958, 36-39; Vēri 1994, 232).

Turpmāk rakstā analizēti 1248. un daḷeji 1252. gada dokumentā minētie Krimuldas draudzes vietvārdi to nosaukšanas secībā.

Vietvārdi Cubesile, Cubesille apzīmēja gan draudzes novadu, gan ciemu. Kubeseles draudze, baznīca un priesteri minēti Indriķa hronikā 13. gs. sākumā, kā arī dokumentos 1231., 1239., 1248., 1338., 1338., 1463., 1496., 1543. gadā (LGU I, 9, 15, 412, 654; SLVA, 234; LUB XII, 237; VTVA, 145). Indriķa hronikā vēstīts, ka 1206. gadā notika lībiešu kristīšana: [..] Alebrands devās uz Turaidu, apveltìdams cilvēkus ar sprediķa vārdu un kristības sakramentu, nodalīja draudzes un uzcēla baznīcu Kubeselē. (IH, X:14) Kubeseles ciems (villa Cubesille) un vaka (Cubbents; Kubbasche wacke) dokumentos ierakstīti 1248., 1550. un 1601. gadā. Turklāt šajā vārdā sauca arī krogu (taberna Kubsel, 1463, LGU I, 412) un no 17. gs. mācītājmuižiņu (Kipsal). Zviedru 17. gs. revīzijās vietvārda pieraksts ir Kiebbisch (1624, 1630), Kubbasch (1638), savukārt vēlāk tas iegūst Kubbiasch, Kubiasch (1744) nosaukumu. 20. gs. sākumā pastāvēja mājvārds Ķizbeles jeb Ķīpsalas (Endzelīns 1922, 44), kas mūsdienās saglabājis Ķizbeles vārdu. Senais lībiešu nosaukums 20. gadsimtā piedzīvojis renesansi un pazīstams kā kultūrvēsturisku un dabas objektu nosaukums: Kubeseles vārdā saukta ala (Runtiņala), pilskalns, kā arī dabas taka. Kubeseles nosaukuma izcelsme, iespējams, saistāma ar lībiešu vecākā Kaupo (Caupo, miris 1217) vārdu. Pastāv pien,ēmums, ka Kubesele bijis Kaupo dzimtais ciems, tam par labu liecina tas, ka Kaupo apglabāts Kubeseles baznīcā (IH, XXI: 4), bet ir gan arī citi vārda etimologijas skaidrojumi, piemēram, tas saistīts ar dabas objekta apzīmējumu - 'padziḷinājumu, kas norobežots no

$\frac{\text { CLXXVI }}{176}$


divām pusēm' (Hermann 897, 8), vai ar lībiešu kub - 'kaudze; kopība, sapulce' (Hirša 1994, 211).

Lìdz mūsdienām nav saglabājies nosaukums Olikenkule, un ir problemātiska tā lokalizācija un saistība ar vēlākiem vietas nosaukumiem Holtczem, Holtetzem (1624); Holtzen (1630); Oll Cehm (1638); Agsimske Pagast (1683), Altzeem (1744) (Auns 2019, 277). Patlaban iespējamā ciema vieta un arī vārds izzudis pavisam, taču 2015. gadā, kad Krimuldas muižas tuvumā atrada ievērojamu dižkoku - egli, to ne tikai iekḷāva aizsargājamo koku sarakstā, bet arī deva tai nosaukumu - Alciema egle. Šis nosaukums izaudzis no lībiešu ciema vārda un mēgināts skaidrot arī vārda etimoloǵiju (skat. http://dziedava.lv; etimologiju skat. arī Hermann 1897, 12).

Ar 13. gs. minēto Kivemale saistāmi 17. gs. nosaukumi wacke Kymnes (1550), Dorf Kymell, Kimell (1624), Kimmel, Kiemall, Kummal (1638), kā arī apciems Ķivmalieši, kas minēts 1922. gadā (Endzelīns 1922, 45), bet mūsdienās zudis. Vārda etimoloǵija saistīta, iespējams, ar lībiešu valodu (igaunu val. kive - 'akmens') (Bielenstein 1892, 367; Hermann 1897, 15).

Nosaukums Cursicule savukārt tiek skaidrots ar etniskas grupas kuršu ciemu lỉbiešu apdzīvotā apgabalā (Ancìtis, Jansons 1963, 43), bet ir arī citas iespējas meklēt vārda etimologiju ('gravas ciems', Hermann 1897, 12). Vietvārds saistāms ar 1463. gada dokumentā līdzās šim ciemam lokalizēto Kuršu jeb Kuršel̦u cel̦u (Kurselscherwech LGU I, 412), kā arī ar 1517. gadā minēto ciemu un pagastu (dorp/Pagast Curszell, Kurszell, LGU II, 230). Lietuvas metrikā minēts Pogost Kursis (1590), savukārt zviedru revīzijās Kursche wacke (1601), Kursische / Kuresische Wacke (1624), Kursische Dorff (1630), Kursische Wacke (1638), Dorff Curseth (1683), Luszitz (1744). 20. gs sākumā pastāvēja apciems Kursīši (Endzelīns 1922, 48), bet mūsdienās apdzīvotas vietas nosaukums ir Sunīši, kura izcelsme saistāma ar mājvārdu, kas minēts jau 1550. gada vaku grāmatā (Auns 2019, 285). Vienlaikus ar Kuršu nosaukumu gan vietas, gan ceḷa apzīmēšanai lietots arī nosaukums, ko var saistīt ar vēsturiskiem Krimuldas pils vārdiem Cremon, Cremun: Krimuldas ceḷš (Crammonscher weg, via Cremonense 1463, LGU I, 412; LUB XII, 237); Krimuldas vaka (1550, Cromonn).

Asigalle ir vietvārds, kas kluva ne tikai par ciema un vakas/pagasta, bet arī muižas apzīmējumu, bet mūsdienās ir izzudis: locus Asegalle (1312, 1454); pagast Azegalle (1496), wacke Assigalsche (1550), Wacke Eisigal (1601), Wacke, Dorf Aysegaysche (1624), Hof Azegall (1504), hoff / guder Azegalle (1509), Hove Asigalle (1517), Hoff Eisigal (1682). Aizgales vakā 
16. gs. vidū ietilpa ciemi Eisigal un Perkus, kā arī muiža. 1922. gadā te atradušies mūsdienās vairs nezināmais Aizgales un Pērkoniešu apciems. Iespējams, ka 13. gadsimtā minētais vietvārds saistīts ar Indriķa hronikā minēto lībiešu vecāko Asi (IH XVI: 4), kā arī vasaḷu dzimtu - Rīgas domkungu vasaḷiem Azgaliem (Krūmiņš 2011, 57). Azgaļu dzimta Rīgas arhibīskapijā sastopama līdz 15. gs. beigām (Thidericus Azegalle de Ropa (1297); Johann and Detlev Asegalle (1360); Asegal (1394, 1397); Jacob Asegall (1465)). Muiža minēta dokumentos arī kā Billes muiža (Billenhoff) (LGU I, 362, 654; LGU II, 29, 78, 230), bet no 17. gs. saukta vairs tikai īpašnieku Engelhartu vārdā (Engelhardz, Engelhardts). Englārtes jeb Engelhartes muiža pastāvēja līdz 20. gs. sākuma agrārajai reformai.

Moisecule - latviešu valodā Muižciems - varētu būt saistīts ar Krimuldas pilsnovada Jaunās muižas (mūsdienās Sējas novads) nosaukumu Moiže vai Muižciems 17. gadsimtā (Beitiņa 1999, 24).

Ennisile Indriķa hronikā, iespējams, minēts kā Anno ciems (Villa Annonis; IH, XI:5; Bielenstein 1892, 52). Laika gaitā te izveidojās muiža, bet 1550. gadā ciema vietu iezīmē wacke Hannis. Muiža 17. gadsimtā saukta gan Ennenberg, gan īpašnieku vārdā - Zögen Hoff (1682/83). Līdz 19./20. gs. mijai ciema apzīmējums saglabāja Anno vārdu (Anno bija lībiešu vecākais, kas dzīvoja 13. gadsimtā) vācu valodas nosaukumā Henneberg, kamēr latviešu nosaukums Sēja saistīts ar īslaicīgu muižas ipašnieku no 1577. gada Andreju Seiju (Westrén-Doll 1926, 12).

Viltisele jeb mūsdienu Vidrižu ciems minēts 13. gs. pirmās puses dokumentos un arī Indriķa hronikā (Vitisele IH, XXIX, 3). Iespējams, to var saistīt ar citu vietu - vēlāko Miltciemu (Miltzeem) Sējas muižas teritorijā (Beitiņa 1999, 24). 1550. gadā vietu iezīmē wacke Maüsel, bet 17. gadsimtā te atradās ciems Wyders, Wettisch Dorp, kā arī muiža Wiedrichs hoff, kas līdz 1652. gadam ietilpa Turaidas pilsnovadā (LGU I, 15, 19, 37). Pamats muižas izveidei bija zemes izdošana lēnu valdījumā - Rīgas arhibīskaps šo lībiešu ciemu jau 1277. gadā izlēn,oja savam vasalim Johannesam no Lunes (Johannes de Lune) (LGU I, 37).

Mundrisile un Totisile ir ciemi, kuri laika gaitā izzuduši, lai arī vēl ir minēti 16.-17. gs. vaku grāmatās un revīzijās kā wacke Totus (Thotis) (1550), Dorff Mindrisch (1638).

Pabasile turpretī saglabāja nosaukumu, kas līdz mūsdienām lietots kā Pabaži. 1550. gadā te atradās wacke Pasobens, bet 17. gs. Paboßmuiße (Biezais 1957, 98), Hoff Babbusch (1624), Babusk Hoff (1638). Vārda etimologiju saista ar lībiešu valodas vārdu salikumu 'purva sala' vai 
'paaugstinājums purvā' (Westrén-Doll 1926, 10). Uzskatīts, ka vieta 1231. gadā dēvēta Vesikendorp, ko varētu saistīt ar personvārdu Vesike, un tas varētu būt pat Indriķa hronikā minētais Gaujas lībiešu vadonis Vesiḳis (Beitiņa 1999, 26).

Vietvārdu Gervicule var atpazīt 13.-17. gs. ciema, vakas, muižas nosaukumos, bet 19. gadsimtā pastāvēja Jērkules pagasts un pagasta skola. Nemainīgi savu nosaukumu saglabā Jērkules ezers. Lībiešu valodā nosaukums nozīmēja 'ezera ciems' (Hirša 1994, 211; Westrén-Doll 1924, 7), un 20. gs. otrajā pusē kolhoza Ezerciems nosaukums tieši saistīts ar šo seno lībiešu vārdu. Vietvārda pieraksts dokumentos ir atšķirīgs - villa Gerwicule (1231, 1309), wacke Terkull (1550), Hoff Jerckill (1624), Dorff klein Jerckell / Dorff gross Jerckell (1624), Hof Gerküll (1638), Hoff Gerkuls (1682).

Ieikisile - mūsdienās Eikaži - tāpat laika gaitā ieguva dažādu vēsturiskajiem centriem raksturīgu statusu, un 13.-17. gs. dokumentos minēts ciems, vaka, muiža - villa Jeckeseile (1252), villa Y[e]kezel (1348); Jekeselle (1350, 1355); wacke Jeikus (1564) (LGU I, 21, 70, 72, 79). 17. gadsimtā te izveidojās neliela muižin,a, kas pastāvēja līdz agrārajai reformai 20. gs. sākumā (Ekaisch (1682), Ekaisch Hoff, Eikasch).

Coltemale - mūsdienās Bīriṇi - saglabāja savu nozīmi kā ciems (Koltemala, Kultezelle, Colteselle, Koltus Zeem), vaka (wacke Goltes, 1564), bet 16. gadsimtā te izveidojās muiža Koltzen, kas vēlāk ieguva Bīriṇu nosaukumu no tās īpašniekiem 16. gs. beigās - 17. gs. sākumā. Vārda saistība ar seno lībiešu valodu tiek meklēta nozīmē kuolta - 'krasts' vai 'smilts kāpu kalns' (Bielenstein 1892, 367; Westrén-Doll 1926, 12), savukārt igaunu valodnieks Karls Augusts Hermanis (Hermann, 1851-1909) saista vārda etimologiju ar somugrisko kulte - 'zelts', līdz ar to tulko nosaukumu kā 'zelta zemes vieta' (Hermann 1897, 15). Bīriṇu vācu nosaukums līdz 20. gs. sākumam bija Koltzen - tuvs latinizētajam 13. gs. lībiešu nosaukumam.

Laugule ir ciems (13.-14. gs. dokumentos tas minēts kā Lovgena, Lawe, Laugele (GU I, Nr. 21, 70, 72, 79)), kā arī Laudas jeb Laugas vaka (1564, Laudisch Wacke). Vēlāk Laugas ciems (Laughas Zeem) piederēja pie Bīriṇu muižas (Auns 2019, 320). Mūsdienās Vidrižu pagastā pastāv Laugas purvs, kura vārdā saglabājušās 13. gs. ciema nosaukuma pēdas. Bīlenšteins uzskatīja, ka šis ir latgaḷu/latviešu izcelsmes vārds (Bielenstein 1892, 367), savukārt citi pētnieki to atzīst par īsti somugriskas izcelsmes vārdu vai lībiešu vārda modulāciju ar nozīmi 'lēzena zeme' (Westrén-Doll 1824, 7; Bušs 1999, 29). 
Salīdzinot vietvārdus, kas minēti latīnu tekstos 1248. un 1252. gadā, ar nosaukumiem, kuri uzskaitīti 1550. un 1564. gadā vācu valodā, var secināt, ka Rīgas arhibīskapijas administratīvais dalījums pilsnovados un draudzēs ar centriem Turaidā un Kubeselē (Krimuldā) pastāvēja vairākus gadsimtus un ka arī 13. gs. latīṇu dokumentos minētie ciemi daḷeji saglabāja savu statusu kā administratīvas vienības - vakas. Vienīgi Kivemale un Mundrisile 16. gs. vidū vairs nebija administratīvas vienības centri Rīgas domkungu pārvaldītajā pilsnovadā. Asigalle - Assigal saglabāja nosaukuma skanējumu, bet citu latinizēto vietvārdu pieraksts 13. gadsimtā krietni atškiras no šādu vietvārdu pieraksta vācu tekstos 16. gs. vidū: Toreida - Trë̈den, Cubesille - Cubbents, Gerwiceule - Terckul, Ennisile - Hannis, Totisile - Thotis, Pabasile - Pasobens, Ieikisile - Jeikus, Coltemale - Goltes, Laugule - Laudisch. Daži ciemi 13. gadsimtā, iespējams, saukti citādāk: Olikencule - Arzim, Moisecule - Kaulen, Viltesile - Maüsel, taču to senie nosaukumi var atkal parādīties vēlāku laiku arklu revīzijās un pat nonākt līdz mūsdienām (kā Viltesile - Vidriži). Mūsdienās vairāki ciemu nosaukumi, kas 1248.-1252. gadā minēti latīnu dokumentos, ir saglabājušies kā vietvārdi un arī toponīmi Krimuldas, Sējas, Vidrižu novadā, bet daži piedzīvojuši zināmu renesansi kā kultūrvēsturisku un dabas objektu nosaukumi, taču dạ̣a ir zuduši vai būtiski mainijuši savu skanējumu.

\section{AVOTI (ar rakstā izmantotajiem saīsinājumiem)}

1. Auns 2019

2. Biezais 1957

3. Brieflade IV

4. Dunsdorfs 1974
Auns, M. Turaidas un Krimuldas pilsnovada 13.-18. gadsimta vēsturiskā ġeogrāfija. Vidzemes 1624./1625. gada arklu revīzija: Turaidas, Krimuldas un Siguldas pilsnovadi. Publicēšanai sagatavojis, tulkojis no vācu valodas un zinātniski komentējis G. Straube. Rīga: Zinātne, 2019, 173-340.

Biezais, H. (Hrsg.) Das Kirchenbuch der St. Jacobskirche in Riga 1582-1621. Uppsala, Wiesbaden: A.-B. Lundequistska Bokhandeln, Otto Harassowitz, 1957.

Brieflade IV Toll, R. V. (Hrsg.). Siegel und Münzen der weltlichen und geistlichen Gebietiger Liv-, Est- und Curland bis zum Jahre 1561 nebst Siegel einheimischer Geschlechter mit 87 Tafeln. Hg. von J. Sachsendahl. In: Est- und Livländische Brieflade. 4. Teil. Reval: Kluge und Ströhm, 1887.

Dunsdorfs, E. (Hrsg.) Der große schwedische Kadaster in Livland 1681-1710. Kartenband. Melnbourne, 1974. 
5. Dunsdorfs 1938 Dunsdorfs, E. (izd.). Vidzemes 1638. g. arklu revīzija. Latvijas Universitates Raksti: Tautsaimniecibas un tiesību zinātnu fakultātes sērija. IV sēj. Rīga, 1938.

6. Endzelīns 1922 Latvijas vietu vārdi. I daḷa: Vidzemes vārdi. Piedaloties A. Ābelei, J. Kauliṇam, P. Šmitam, savācis un rediǵējis J. Endzelīns. Rīgā, 1922.

7. $\mathrm{IH}$

Indriķa hronika / Heinrici Chronikon. Ābrama Feldhūna tulkojums, Ēvalda Mugurēviča priekšvārds un komentāri. Rīga: Zinātne, 1993.

8. LGU I Bruining, H. V., Busch, N. (Hrsg.). Livländische Güterurkunden. 1207-1500. Bd. 1. Riga: Jonck \& Poliewsky, 1908.

9. LGU II Bruining, H. V. (Hrsg.). Livländische Güterurkunden. 1500-1545. Bd. 2. Rīga: A. Gulbis, 1923.

10. LNB RXA32, 17 Latvijas Nacionālā Bibliotēka, Reto grāmatu un rokrakstu nodaḷa, Matīsa Siliṇa personālais fonds.

11. LUB I

Bunge, F. v. (Hrsg.). Liv-, Esth- und Curländisches Urkundenbuch nebst Regesten. Bd. 1. Reval: Kluge und Ströhm, 1853.

12. LUB XII

Schwartz, P., Bulmerincq, A. v. (Hrsg.). Liv-, Est- und Curländisches Urkundenbuch. Abt. 1. Bd. 12: 1460-1472. Riga; Moskau: J. Deubner, 1910.

13. LVVA-4060-2-30 Latvijas Valsts vēstures arhīvs, 4060. fonds "Latvijas vēstures institūta dokumentu kolekcija".

14. Inventarium Rīgas arhibīskapijas inventārs "Inventarium zur Erzstift Riga". zur Erzstift Kopija Turaidas muzejrezervāta zinātniskajā arhīvā TMR za IM Riga 1564

15. SLVA II nod. 802.

Švābe, A. (izd.). Senās Latvijas vēstures avoti (līdz 1256). 2. burtn. Rīga: Latvijas vēstures institūta apgādiens, 1940.

16. Švābe 1939 Švābe, A. (izd.). Daži Livonijas saimniecības vēstures avoti 1540.-68. g. Latviešu vēsturnieku veltījums profesoram Dr. hist. Robertam Viperam. 14. VII 1859 / 14. VII 1939. Rīga: A. Gulbis, 1939.

17. Wackenbuch auf Turaidas vaku grāmata "Wackenbuch auf der Treidichen Seiten Im der Treidichen Erzstift Riga". Kopija Turaidas muzejrezervāta zinātniskajā arhīvā Seiten 1550 TMR za IM II nod. 754.

18. VTVA Švābe, A. (izd.). Vidzemes tiesību vēstures avoti 1336-1551. Rīga: Latvijas vēstures institūta apgādiens, 1941.

\section{TEORĒTISKĀ LITERATŪRA}

1. Ancītis, Jansons, 1963 Ancītis, K., Jansons, A. Vidzemes etniskās vēstures jautājumi. Arheoloǵija un etnogrāfija V, 1963, 25-66.

2. Ariste 1954

Аристэ, П. К вопросу о развитии ливского языка. Труды Института языкознания АН СССР 4, 1954, 254-307.

$\frac{\text { CLXXXI }}{181}$


3. Ariste 1958

4. Auns 2009

5. Balode 2009

6. Beitina 1999

7. Bielenstein 1892

8. Bušs 1999

9. Bušs 2003

10. Dunsdforfs, Spekke 1964

11. Gadebusch 1780

12. Hagemeister 1836

13. Hermann 1897

14. Hirša 1994

15. Krūmiņš 2011

16. Levāns 2013
Аристэ, П. Аивы и дивский язык. Eesti NSV Teaduste Akadeemia Toimetised.Ühiskonnateaduste seeria 7, 1, 1958, 37-46.

Auns, M. Turaidas un Krimuldas novada apdzīvotība un iedzīvotāju etniskā piederība Livonijas laikā. Pa somugru pēdām Baltijas jūras krastā. Starptautiskās zinātniskās konferences materiāli, 2009. gada 23. aprīlis, Turaida. Rīga: Zinātne, 2009, 53-58.

Balode, L. Par dažiem somugru cilmes hidronīmiem Latvijā. Pa somugru pēdām Baltijas jūras krastā. Starptautiskās zinātniskās konferences materiāli, 2009. gada 23. aprīlis, Turaida. Rīga: Zinātne, 2009, 37-41.

Beitiṇa L. Rakstītās ziṇas par Turaidas un Kubeseles līvu ciemiem. Gaujas lībieši Latvijas kultūrvēsturē: apdzīvotības problèmas. [Rīga]: Nordik, 1999, 22-27.

Bielenstein, A. Die Grenzen des lettischen Volksstammes und der lettischen Sprache in der Gegenwart und im 13. Jahrhundert: ein Beitrag zur ethnologischen Geographie und Geschichte Russlands. St. Petersburg, 1892.

Bušs, O., Beitiņa, L. Daži Turaidas un Kubeseles novada vietvārdi (12.-13. gs.). Gaujas lībieši Latvijas kultūrvēsturē: apdzīvotības problēmas. [Rīga]: Nordik, 1999, 28-29.

Bušs, O. Kādi ir senākie lībiešu personvārdi un vietvārdi: Personvārdi, vietvārdi un citi vārdi: izpētes pakāpieni. Rīga, 2003, 69-70.

Dunsdorfs, E., Spekke, A. Latvijas vēsture 1500-1600. Stokholma: Daugava, 1964.

Gedebusch, K. F. Livländische Jahrbücher 1 Theil: 1030-1561. Riga: Hartnock, 1780.

Hagemeiter, H. Materialien zu einer Geschichte der Landgüter Livlands. Riga, 1836.

Hermann, K. A. Ueber die etymologische Bedeutung der alten livischen und kurischen Ortsnamen. Sitzungsberichte der Gelehrten Estnischen Gesellschaft zu Dorpat 1896. Dorpat, 1897.

Hirša, Dz. Lībieši un lībiešu izcelsmes vietvārdi Latvijā. Lìbieši: rakstu krājums. Rīga, 1994, 201-215.

Krūmiṇš, G. (red.). Krimuldas novada vēsture: Ragana, Turaida, Inciems, Eikaži, Lēdurga, Aijaži. Rīga: Jumava, 2011.

Levāns, A. Politiskās organizācijas modeḷi viduslaiku Livonijā 13.-16. gadsimtā. Grām.: Stradiṇš, Jānis (galv. red.). Latvieši un Latvija. 2. sēj.: Jundzis, T., Zemītis G. (atb. red.). Valstiskums Latvijā un Latvijas valsts - izcīnītā un zaudētā. Rīga: Latvijas Zinātṇu akadēmija, 2013, 52-76. 
17. Liepiņa 1978

18. Mägiste 1967

19. Pajusalu 2009

20. Simiński 2007

21. Stikāne 2014

22. Stryk 1885

23. Šterns 2002

24. Vääri 1966

25. Vegesack 1932

26. Vēri 1994

27. Vunk 2014

28. Westrén-Doll 1926

29. Zeids 1992
Liepiņa, Dz. Par ciema novadu Vidzemē. Arheologija un Etnogrāfija. XII sēj.: Apcerējumi par Latvijas teritorijas apmetnēm, celtnèm un tajās atrasto numismātisko materiālu pirmatnējās kopienas un feodālisma periodā. Rīga, 1978, 138-159.

Mägiste J. Úber die ältesten Aufzeichnungen des Estnischen und Livischen. Különlenyomat. A Nyelvtudományi értekezésesk 58. számábol. Tartu, 1967, 147-155.

Pajusalu, K. Concerning Salaca Livonian as a Southern Finnic dialect (Par Salacas lībiešu valodu kā dienvidsomu dialektu). Pa somugru pēdām Baltijas jūras krastā. Starptautiskās zinātniskās konferences materiāli, 2009. gada 23. aprīlis, Turaida. Rīga: Zinātne, 2009, 42-48.

Simiński, R. Die lokalen Grenzen in Livland im 13. und 14. Jahrhundert. Entstehung und Funktion. In: Grenze und Grenzüberschreitung im Mittelalter (Knefelkamp, U., Bossemann-Cyran, K., eds.). Berlin: Akademie Verlag, 2007.

Stikāne, V. (sast.). Turaida 13.-16. gadsimta dokumentos. Rīga: Zinātne, 2014.

Stryk, L. Bieträge zur Geschichte der Rittergüter Livlands. 2. Theil: der lettische Distrikt. Dresden, 1885.

Šterns, I. Latvijas vēsture 1180.-1290. Krustakari. Rīga: Latvijas vēstures institūta apgāds, 2002.

Vääri, Е. Яивский язык. Языки народов СССР, т. 3. Москва, 1966.

Vegesack: M.v. Die untergangenen Dörfer in den sieben nördlichen Kirchspielen des Ehemaligen Erzstift Riga. Sitzungsberichte der Gesellschaft für Geschichte und Altertumskunde zu Riga. Vorträge aus dem Jahre 1931/32. Riga, 1932, 13-24.

Vēri, E. Par lībiešiem un lībiešu valodu. Lìbieši: rakstu krājums. Rīga, Zinātne, 1994, 227-247.

Vunk, A. Metsepole Livonians from the $14^{\text {th }}$ to the $17^{\text {th }}$ century. Eesti ja soome-ugri keeleteaduse ajakiri - Journal of estonian and Finno-Ugric Linquistics. Tartu, 2014, 5, 37-60.

Westrén-Doll, A. Urkundliche livische und kurische Ortsnamen. Sitzungsberichte der gelehrten estnischen Gesellschaft zu Dorpat 1924. Dorpat: C. Mattiesen, 1926, 5-24.

Zeids, T. Senākie rakstītie Latvijas vēstures avoti līdz 1800. gadam. Rīga: Zvaigzne, 1992. 


\section{MEDIEVAL PARCHMENT DOCUMENTS AND \\ LIV PLACE NAMES}

\section{SUMMARY}

The present paper focuses on the Latin documents written in Turaida Castle in the first half of the $13^{\text {th }}$ century and the place names, which are published in the book Turaida in the $13^{\text {th }}-16^{\text {th }}$ Century Documents (2014). The publication summarizes information from written historical sources that mention the name of Turaida in various contexts, including that of a place name. The present name of Turaida is derived from Liv language, which belongs to the Finno-Ugrian family. In the Middle Ages, the name had several written variations reflecting the efforts to emulate the phonetic sounding of the Liv language in the Latin and Middle-Low German languages: Thoreyda, Thoreida, Toreidhia, Torreyde.

The book contains data obtained from parchment documents, chronicles, letters, deeds and other written sources which are arranged here in chronological order. The first part of this book covering the time of Bishops of Riga Albert (1199-1229) and Nicholas (1230-1253) comprises the texts originally written in Latin, including four parchment documents issued in Turaida.

The oldest documents, which were issued in Turaida (1239-1252) hold information about the formalization of the tenure of lands, and several of them are related to the provision for the Cathedral Chapter of Riga. These documents contain a wealth of facts about the density of the population in medieval Krimulda (Cremon) Castle district. Combined with the sources from the middle of the $16^{\text {th }}$ century and the land auditions from the $17^{\text {th }}$ century, this information allows the localizing of the places, which are mentioned in the $13^{\text {th }}$ century documents. It also enables trace the disappearance of the Liv villages as the dominating type of settlement, thus building a base for the studies of ethnic processes in the surroundings of Turaida over the course of several centuries. 